УДК 378:373.3

DOI:

Ліліана Хімчук, кандидат психологічних наук, доцент кафедри фахових методик $i$ технологій початкової освіти, педагогічного факультету ДВНЗ "Прикарпатський національний університет імені Василя Стефаника"

\title{
ПІДГОТОВКА ВЧИТЕЛІВ ПОЧАТКОВИХ КЛАСІВ ДО РОЗВИТКУ ПРОФЕСІЙНИХ ЗАЦІКАВЛЕНЬ УЧНІВ НА ОСНОВІ ВИКОРИСТАННЯ ТЕОРІЇ МНОЖИННИХ ІНТЕЛЕКТІВ
}

У статті здійснено теоретичний аналіз досліджень вітчизняних і зарубіжних учених, наукові пошуки яких присвячені проблемам професійної підготовки майбутніх вчителів у сфері розвитку ранніх професійних зачікавлень учнів початкових класів.

Концептуальний підхід автора полягає у використанні теорї множсиного інтелекту Г. Гарднера як методологічної основи підготовки вчителів початкових класів до діагностики, формування і розвитку ранніх професійних інтересів учнів. Рекомендовано доповнити зміст професійної підготовки майбутніх учителів початкових класів тематикою, пов 'язаною з формуванням умінь діагностувати й розвивати ранні професійні зацікавлення дітей.

Ключові слова: підготовка вчителів початкових класів; розвиток професійних зацікавлень; теорія множинного інтелекту.

Лim. 11.

Liliana Khimchuk, Ph.D.(Psychology), Pedagogical Faculty, "Vasyl Stefanyk Precarpathian National University"

\section{PREPARATION OF PRIMARY SCHOOL TEACHERS FOR THE DEVELOPMENT OF STUDENTS' PROFESSIONAL INTERESTS ON THE BASIS OF USING THE THEORY OF MULTIPLE INTELLIGENCES}

The article provides a theoretical analysis of research by domestic and foreign scientists, whose works are devoted to the problems of professional training of future teachers in the field of the primary school students' early professional interests' development. The author's conceptual approach consists in using the G. Gardner's theory of multiple intelligence as a methodological basis for preparing the primary school teachers for the diagnosis, formation and development the early professional interests' of students.

The author details the main provisions of the theory of multiple intelligences, describes the types of intellects that express ways of capturing and processing information by people: linguistic, mathematical-logical, kinesthetic, visual-spatial, musical, intrapersonal, interpersonal, natural, existential. The features identifying different types of intelligence of primary school pupils are characterized. Based on the research of foreign scientists, the directions of early professional orientation of students have been developed, the list of professions that best corresponding to each of the types of intelligence of the child has been determined.

The author believes that a primary school teacher should support and develop the dominant type of the pupils' intelligence in the educational process, consult the parents to predict the possible professional orientation in the future. A list of recommended questions has been formulated for parents of students to better systematize their observations of child at home. The article emphasizes that for teachers who diagnose and guide students to develop their professional interests, it is important to monitor and notice changes in today's labor market, know the professions that will be most needed in the near future, if necessary, consult with experts on this issue. It is recommended to supplement the content of professional training of future primary school teachers with topics related to the formation of skills to diagnose and develop early professional interests of children.

Keywords: training of primary school teachers; development of professional interests, theory of multiple intelligence.

“У кожній дитині треба побачити питання, ту божу іскру, яку вихователь завдяки мистецтву виховання, пройнятого любов'ю, має вирімувати доти, доки ия дитина не знайде саму себе".

Рудольф Штайнер

$\Pi$ остановка проблеми у загальному вигляді та її зв'язок із важливими науковими i практичними завданнями. Час панування й розвитку інформаційного суспільства, час експансії інформаційних технологій в усіх сферах 


\section{ПІДГОТОВКА ВЧИТЕЛІВ ПОЧАТКОВИХ КЛАСІВ ДО РОЗВИТКУ ПРОФЕСІЙНИХ ЗАЦІКАВЛЕНЬ УЧНІВ НА ОСНОВІ ВИКОРИСТАННЯ ТЕОРІЇ МНОЖИННИХ ІНТЕЛЕКТІВ}

суспільного життя, вимагає якісно нових змін і в галузі підготовки педагогічних кадрів, яким народ довіряє найцінніше - теперішнє і майбутнє своїх дітей. Сьогодні нові технології у різних наукових сферах, дають змогу вчителю постійно й швидко підвищувати професійний рівень, вдосконалювати майстерність, бути потрібним тим, хто народився у цифрову еру. Слушними $є$ слова видатного педагога-новатора Ш. Амонашвілі: “Педагог виховує нову людину, людину майбутнього, тому необхідно, щоб він сам уособлював найвищі риси нової людини, сам уособлював людину 3 майбутнього" $[5,13]$.

Великою мірою саме від учителя початкових класів залежить успішність реалізації дитиною свого потенціалу. Проте теперішня підготовка вчителів початкових класів зорієнтована в основному на забезпечення учнів знаннями й недостатньо орієнтує їх на життєве і професійне самовизначення.

Питанням професійного спрямування у початковій школі не приділяється належної уваги, оскільки вважається, що у молодших школярів ще немає підстав для здійснення серйозного професійного вибору, часто відсутні виражені інтереси й нахили, які легко змінюються. Учителі, відповідно до розроблених державних програм, уважають достатнім розвиток інтересу до професії батьків, до найбільш масових професій та формування в учнів любові й сумлінного ставлення до праці. Та цього, на жаль, виявляється замало. Як свідчать опитування, значна частина випускників середніх загальноосвітніх закладів не мають визначених професійних намірів, перебувають у стані невизначеності, непевності, що завжди $\epsilon$ супутниками страху перед майбутнім. Змінити цю ситуацію, можна тільки кардинально змінивши підходи до підготовки вчителя у питаннях його компетентності щодо розвитку професійних зацікавлень молодших школярів. У контексті цього актуалізується проблема підготовки вчителів початкових класів до формування ранніх професійних зацікавлень молодших школярів 3 урахуванням сучасних досягнень світової науковопедагогічної спільноти.

Аналіз основних досліджень і публікацій. У вітчизняному освітньому просторі проблема професійної підготовки вчителя, формування його методичної готовності до різних видів діяльності, ідеї впровадження педагогічної майстерності та творчості є предметом дослідження багатьох науковців [2]. Значний доробок з означеної проблематики міститься у працях С. Гончаренка, I. Зязюна, М. Лещенко, Л. Хомич. Проблемою методичної підготовки учителя початкових класів до формування ранніх професійних інтересів в учнів займалася Л. Тимчук. Досить глибоко і детально українськими науковцями С. Мельничуком, Н. Побірченко, В. Тименком досліджено проблеми підготовки покоління, що підростає, до професійного самовизначення. Психологопедагогічним основам підготовки молоді до вибору фаху та вивченню соціально-економічних передумов професійного самовизначення присвячені дослідження Г. Балла, Г. Костюка, В. Моляко, Б. Федоришина. Заслуговують на увагу грунтовні праці Ш. Амонашвілі, Л. Занкова, Н. Бібік, Л. Виготського, О. Савченко в яких визначено методичні, технологічні та практичні аспекти освітнього процесу початкової ланки освіти. Зарубіжні науковці-педагоги Т. Армстронг, Е. Висоцька, Г. Гарднер, Т. Гордон, К. Шмідт плідно вивчають шляхи підготовки вчителів до креативної діяльності, що гармонізує й створює передумови для успішного професійного спрямування молодших школярів. Особливий інтерес для дослідження становлять праці українських дослідників В. Гринько, Н. Лавриченко, М. Лещенко, В. Тименка, присвячені вивченню зарубіжного досвіду щодо впровадження теорії множинного інтелекту в освітні реалії $[3 ; 4 ; 6]$.

Мета статті - вивчення проблеми підготовки вчителів початкових класів до розвитку професійних зацікавлень учнів на основі використання теорії множинного інтелекту Г. Гарднера.

Виклад основного матеріалу. Коло питань щодо необхідності підготовки молодого покоління до усвідомленого вибору професійного шляху, успішного подолання життєвих викликів, всебічний розвиток їх здібностей та обдарувань завжди було предметом наукових-педагогічних досліджень, дискусій, розвідок. Велику роль у розв'язанні означеної проблеми відіграють уміння вчителя початкових класів цілеспрямовано організовувати освітній процес, в ході якого розвивати в учнів здатність допрофесійно-спрямованого інформаційного збагачення, діагностувати їхні здібності, таланти, професійні інтереси та створювати умови, що сприяють формуванню особистісних якостей відповідно до прогнозованої професійної діяльності.

На нашу думку, важливим підгрунтям та ефективною допомогою у підготовці вчителів початкових класів до розвитку професійних зацікавлень учнів може стати розроблена професором Гарвардського університету, всесвітньовідомим американським вченимпсихологом, спеціалістом у галузі когнітивної 


\section{ПІДГОТОВКА ВЧИТЕЛІВ ПОЧАТКОВИХ КЛАСІВ ДО РОЗВИТКУ ПРОФЕСІЙНИХ ЗАЦІКАВЛЕНЬ УЧНІВ НА ОСНОВІ ВИКОРИСТАННЯ ТЕОРЇ̈ МНОЖИННИХІНТЕЛЕКТІВ}

психології, пізнання та творчості Говардом Гарднером (Howard Gardner), теорія множинного інтелекту, що стала революційною в розумінні інтелектуальних здібностей людини [1]. Ця теорія швидко знайшла послідовників у всьому світі й стала неоціненним надбанням педагогічних систем різних країн.

Створена у 1983 р., теорія множинного інтелекту стала результатом багаторічних досліджень та проєктів співпраці провідних Гарвардських вчених у галузі когнітивних досліджень. Ця теорія розпочала революцію щодо розуміння процесу розвитку інтелекту в навчанні. Традиційно діагностика інтелектуального потенціалу базувалась на результатах тестових випробувань на IQ, які показували, що людина “розумна”, “нормальна” або “з відхиленнями”.

Г. Гарднер доводить, що інтелект людини $є$ динамічним, багатовимірним і виходить за межі можливостей лінгвістично-логічних здібностей, які традиційно діагностуються у процесі навчання. Ця теорія передбачає, що інтелект має не одну особливість, яка описує людські можливості в галузі інтелектуальної діяльності, й існує кілька типів інтелекту залежно від того, про який вид діяльності іде мова. Вчений у розробленій теорії виокремлює та пояснює різні види інтелекту.

Американський психолог припускає, що зводити визначення інтелекту дитини до простої перевірки IQ недостатньо. Академічна успішність, безсумнівно, важлива, але настільки ж важливі й схильності дитини до малювання, музики, танців, підприємницької діяльності тощо. Всі ці схильності необхідно враховувати, визначаючи потенціал дитини. Так виникла теорія множинного інтелекту, яка доводить, що в людини існує дев’ ять видів інтелекту, кілька з яких можуть домінувати.

Г. Гарднер виділяє дев'ять видів інтелекту, серед яких: лінгвістичний (мовний, вербальний); математично-логічний; кінестетичний (руховий); візуально-просторовий; музичний; природничий; внутрішньо-особистісний (інтраперсональний); міжособистісний(інтерперсональний); екзистенційний [10].

Основні положення теорії множинного інтелекту Говарда Гарднера полягають у наступному: кожна людина має всі види інтелекту, розвинені різною мірою; різні види інтелекту та рівень їх розвитку роблять людину унікальною, відрізняючи їі від інших; рівень розвитку різних видів інтелекту людини є змінним і динамічним у процесі її життя; види інтелекту взаємодіють у різних поєднаннях один з одним; види інтелекту розвиваються завдяки різним видам діяльності; види інтелекту - це потенціали, які можна активувати в процесі діяльності; всі види інтелекту рівноцінні [1].

Донедавна в суспільстві було прийнято вважати, що успішність дитини в школі є єдиним показником, який визначає іiі потенціал. Коли дитина дорослішає, більшість батьків хочуть, щоб вона стала всебічно розвиненою й успішною в різних сферах життя. Але перш ніж вона піде до школи, батьки, ознайомившись 3 теорією множинного інтелекту, повинні зрозуміти - кожна дитина розумна (має всі 9 видів інтелекту) і у чомусь обов'язково виявиться сильною, попри їі оцінки та фізичну форму (за винятком окремих складних психічних захворювань).

Батьки повинні з раннього віку дитини навчитися розпізнати ознаки, які характеризують iiі вид інтелекту. Якщо батьки почнуть розвивати ці риси з раннього віку, то зможуть оцінити іiі потенціал і зрозуміти, що це може бути важливішим, ніж успішність 3 математики або фізики. У цьому контексті цікаві дані знаходимо у дослідженні Л.Тимчук, що займалась проблемою підготовки вчителів початкових класів до розвитку ранніх професійних інтересів учнів: “Слушними постають питання про те, з якого ж віку можна і потрібно формувати професійні інтереси та проводити діагностику профорієнтаційної спрямованості [8]. Десятиріччями фахівці з педагогіки, вікової психології, фізіологи й практичні психологи ретельно вивчали характеристики й особливості дітей різного віку і виявили багато процесів становлення особистості, у тому числі й те, що 90\% показників, які впливають на формування характеру людини, закладаються у віці до 34 місяців 3 моменту народження. 3 50-х р. XX ст. нейробіологи та психологи, активно займаючись вивченням зв'язку між досвідом (сенсорним, перцептивним, руховим) дитини, антропометричними змінами й розвитком певних зон головного мозку, дійшли висновку, що зростання мозку відбувається не тільки внаслідок збільшення розмірів нейронів, але й завдяки збільшенню числа зв'язків між ними. При цьому найактивнішим періодом цього процесу є 27 тижнів 3 моменту зачаття та 30-50 місяців 3 моменту народження, що відповідає 2,5 рокам життя дитини. Найбільш показові ознаки цього процесу - співвідношення об'єму мозку дорослої людини й дитини. Мозок новонародженого за розмірами й вагою становить 25 \% мозку дорослої людини. До кінця першого року життя це співвідношення дорівнює $50 \%$, до кінця другого року - $75 \%$, до 2,5-2,7 років - $90 \%$, до 25 років - $100 \%$. Таким чином, до кінця 30-32 


\section{ПІДГОТОВКА ВЧИТЕЛІВ ПОЧАТКОВИХ КЛАСІВ ДО РОЗВИТКУ ПРОФЕСІЙНИХ ЗАЦІКАВЛЕНЬ УЧНІВ НА ОСНОВІ ВИКОРИСТАННЯ ТЕОРІЇ МНОЖИННИХ ІНТЕЛЕКТІВ}

місяців життя дитини нейробіотичні, психологічні, антропометричні та інші вроджені ознаки мають максимальний прояв. До цього віку відбувається остаточне формування вроджених даних, які потребують розвитку і можуть бути або розвиненими, або ні [7, 209].

3 вище зазначеного стає зрозумілим: що чим раніше ми почнемо виявляти та розвивати різні види інтелекту дитини, то краще можемо зорієнтувати іiі у виборі майбутньої професійної діяльності.

На нашу думку, підготовка сучасного вчителя початкових класів до формування ранніх професійних зацікавлень повинна здійснюватися 3 урахуванням наукових досягнень Г. Гарднера зокрема, опанування теорії множинного інтелекту [10].

Коротко схарактеризуємо деякі з видів інтелектів, виокремлені американським ученим у контексті їх розвитку та впливу на формування ранніх професійних зацікавлень в учнів початкових класів.

1. Візуально-просторовий інтелект - це здатність розуміти форми, площини, кольори, лінії та розміри. Учитель початкових класів може визначити розвиненість цього виду інтелекту в учня за такими ознаками: у дитини добре розвинені уява й візуалізація, вона чутлива до навколишніх предметів (швидко й легко сприймає, адаптується до предметного середовища) кольорів та візерунків, любить, малювати, ліпити та виготовляти цікаві роботи, використовуючи різні кольори та види матеріалів, захоплюється складанням кольорових композицій, пазлів розгляданням картографічних зображень; у таких учнів чудово розвинене бачення колористики в композиції, їм подобається діяльність, що потребує залучення уяви й візуалізації. Учителю слід звертати увагу на те, чи можуть вони відтворити в пам'яті зображення, предмети та пов'язані з ними емоційні асоціації, викликати в уяві образи, що були уявлені ними раніше й запам'ятались, пригадувати спогади за допомогою зображень (візуалізація).

Не повинно залишатися поза увагою учителя i те, наскільки учні спостережливі й уважні до різних дрібниць у навколишній дійсності; чи отримують задоволення від розбирання та складання різних елементів в одне ціле; чи люблять в ігровій діяльності моделювати, складати тривимірні пазли, конструктори (з блоків робити будинки, моделі машин, тварин тощо); чи люблять учні малювати й багато малюють, чи можуть представити власні ідеї графічно, чи орієнтуються у тривимірному просторі. У випадку наявності в учнів вищеперерахованих особистісних характеристик, можна говорити про розвинутий у них візуально-просторовий вид інтелекту.

Учитель початкових класів, повинен не тільки сам підтримувати й розвивати виявлений домінантний вид інтелекту в освітньому процесі, а й стати консультантом батьків дитини щодо прогностики можливого професійного спрямування дитини в майбутньому. Коли у дитини добре розвинений візуально-просторовий тип інтелекту, батьки мають знати, що в майбутньому вона може себе успішно реалізувати, приміром у такій професійній діяльності, як інженер, архітектор, геодезист, дизайнер інтер'єрів, дизайнер комп'ютерних ігор, декоратор інтер'єру та ін. В цих професіях потрібно легко уявляти собі тривимірність об'єктів, що рухаються у просторі, моделювати навколишній простір [11].

2. Лінгвістичний інтелект (словесний, мовний) - це здатність до майстерного використання слів в усному та писемному мовленні, що включає вміння збирання й запам'ятовування словесної інформації.

Учителям початкових класів важливо знати, що цей вид інтелекту розвивається при вільному вираженні словами, слуханні та словесному описі елементів навколишнього світу, а також шляхом читання, написання оповідань, ведення щоденників. Слід зазначити, що на розвиток лінгвістичного інтелекту найбільше спрямована сучасна модель освіти; за яким, в переважній більшості, й визначається успішність у школі. Діагностуючи цей вид інтелекту в учнів, потрібно зазначати, наскільки вони чутливі до слів, їх порядку, звуку, ритму, голосової модуляції, чи проявляють інтерес до мови, слухання та читання книжок, експериментують зі словами (трансформують слова, граються, вигадуючи нові слова, рими, люблять словникові ігри, вигадують „свою” мову), вміють використовувати вербальні засоби для формування настрою, переказувати прочитане чи почуте, переконувати словом.

Виходячи із вищезазначеного, учитель початкових класів може зробити прогностичне припущення щодо професійної спрямованості таких учнів й рекомендувати як можливий вибір для їх успішної реалізації такі професії: вчитель мови, викладач, редактор, перекладач, логопед, секретар, стенограф, коректор, бібліотекар, архівіст, політик, письменник, поет, диктор радіо чи телебачення, журналіст, юрист, помічник керівника юридичної фірми [11].

3. Математичний-логічний інтелект - це здатність мислити абстрактно, розуміти числа, 


\section{ПІДГОТОВКА ВЧИТЕЛІВ ПОЧАТКОВИХ КЛАСІВ ДО РОЗВИТКУ ПРОФЕСІЙНИХ ЗАЦІКАВЛЕНЬ УЧНІВ НА ОСНОВІ ВИКОРИСТАННЯ ТЕОРІЇ МНОЖИННИХ ІНТЕЛЕКТІВ}

використовувати їх, встановлюючи зв'язки між різними явищами, причинами явищ та їх наслідками. Учителям початкових класів, щоб виявити рівень розвитку цього типу інтелекту, потрібно взяти до уваги учнів, які добре логічно мислять, люблять використовувати цифри та зразки (наочні, числові, орнаментальні), їм подобається працювати з числами, формулами, оперувати математичними обчисленнями. Підтримуючи та розвиваючи математичнологічний вид інтелекту, учителі можуть спрямовувати учнів у подальшому професійному майбутньому на вибір фаху, що пов'язаний 3 управлінням фінансами, складанням бюджету, проведенням економічних досліджень. Учням та їх батькам можна рекомендувати вибір професій, де необхідні компетентності в царині формулювання гіпотез, оцінки, ведення рахунків, здійснення підрахунків та розрахунків, використання статистичних даних, проведення аудиту, де необхідно робити логічні умовиводи, аналізувати, створювати таксономії, класифікації, ідентифікаційні послідовності. До переліку професій, що можна розглянути, належать: бухгалтер, аудитор, економіст, спеціаліст у сфері публічних закупівель, страховий агент, математик, науковець, вчений у галузі точних наук, викладач математичних дисциплін, статистики, комп'ютерний аналітик, технік, планувальник, програміст, детектив, адвокат та ін. [11].

4. Музичний інтелект (слуховий, ритмічний) - це здатність чутливо розрізняти ритм, мелодію, темп, звуки, що надходять 3 навколишнього світу, отримання інформації, знань за допомогою опрацювання звуків (мислення звуками). Для діагностики цього виду інтелекту, вчителі початкових класів мають зосереджуватися на виявленні в учнів любові до музики, ритму, чутливості до впливу звуків навколишнього середовища (наприклад, співу птахів, звуків дощу, шуму вітру), а також на тому, як сильно впливають ритм та тональність звуків на дітей, чи краще засвоюється навчальний матеріал під музику (інколи учень, слухаючи чи опрацьовуючи навчальний матеріал, щось собі наспівує, мугикає, бурмотить), чи легко відтворюють почуту нову мелодію та ін. Розвивається музичний тип інтелекту під час музичних ігор, слухання музики, співу, ритмічних вправ, створення музики за допомогою відповідних комп'ютерних програм та ігор.

3 метою виявлення в учнів музичного типу інтелекту, вчителі початкових класів можуть залучити до співпраці батьків, запропонувавши їм більш зосереджено поспостерігати за своїми дітьми й дати відповіді на такі запитання: чи люблять Ваші діти співати та слухати музику? Чи легко Вашим дітям дається вивчення пісень, віршів, скоромовок, лічилок, дитячих рим? Чи спокійно Ваші діти сприймають музичний стиль “реп”, наскільки нескладно їм дається його розуміння? Чи подобається Вашим дітям читати разом з Вами? Чи чують та реагують на них Ваші діти різні випадкові, віддалені шуми? Чи слухають Ваші діти музику (вибивають ритм, наспівують, бурмочуть) під час виконання домашніх завдань чи навчаючись чогось нового (люблять навчитися під акомпанемент музики)? Чи Ваші діти співають або грають на музичному інструменті? Чи люблять Ваші діти музичні та анімаційні фільми, цифрові музичні ігри? Чи легко Ваші діти розпізнають ритм та різні мелодії? Чи Ваші діти краще й довше пам'ятають дати, математичні формули та періодичні таблиці, якщо при їх вивченні був використаний “реповий” (речитативний) стиль запам’ятовування, чи вони були проспівані у жвавому ритмі, ніж їх просто багаторазово повторює знайомий голос учителя?

Систематизувавши свої спостереження 3 опитуванням батьків щодо рівня розвитку музичного інтелекту в учнів, у разі діагностування його високого рівня, учителі можуть рекомендувати учням майбутній професійний вибір, що буде пов'язаний 3 музикою, пї створенням, аранжуванням, записом, музичною критикою (аналізом музичних стилів, виконавської майстерності), співом, грою на музичних інструментах та ін. Серед професій до рекомендованого списку можна віднести такі: музикант, музичний терапевт, ді-джей (DJ), аранжувальник, фахівець 3 продажу музичних інструментів, автор пісень, інженер студії звукозапису, менеджер хору, композитор, диригент, інструменталіст, співак, викладач музики та ін. [11].

5. Кінестетичний (руховий) інтелект - це здатність мислити, виражати почуття, ідеї, здібності до розв'язання проблем через рухову активність (рух, координація рухів, гнучкість). Учителі початкових класів, спостерігаючи в освітньому процесі за поведінкою учнів з добре розвиненим кінестетичним інтелектом, помічають, що їм подобається рухова активність (рухливі ігри, танці, спортивні змагання, різні фізичні вправи на розвантаження), їх рухи добре скоординовані, вони добре спілкуються використовуючи “мову тіла" і жести. Для правильного виконання завдань здебільшого, мають побачити, як це роблять інші.

Залучаючи батьків до співпраці щодо кращого 


\section{ПШДГОТОВКА ВЧИТЕЛІВ ПОЧАТКОВИХ КЛАСІВ ДО РОЗВИТКУ ПРОФЕСІЙНИХ ЗАЦІКАВЛЕНЬ УЧНІВ НА ОСНОВІ ВИКОРИСТАННЯ ТЕОРІЇ МНОЖИННИХ ІНТЕЛЕКТІВ}

діагностування не тільки рівня розвитку кінестетичного інтелекту їх дитини, а й їі професійних зацікавлень, можливого найбільш відповідного спрямування їі до майбутнього професійного вибору, можна запропонувати їм описати рухливу активність дитини. В цьому описі, який можна назвати “Кінестетичний портрет” учня, слід зазначити, наскільки подобаються йому фізичні вправи (розминки, руханки), рухливі ігри, танці, рольові вправи, які вимагають акторської гри, драматизації та міміки. Описати як любить відпочивати дитина (добре почувається під час поїздок у нові місця, віддає перевагу активному відпочинку на повітрі, груповим рухливим іграм з постійною зміною зон у приміщенні, вміє придумувати нові інтерактивні ігри, що передбачають переміщення в просторі).

Створюючи такий портрет, слід зазначити також, чи $є$ у дитини почуття контролю над власним тілом (контролює свої рухи, добре маніпулює різними предметами, пізнає навколишні предмети на дотик, чутливий до дотику та ін.), наскільки є вправною у фізичній діяльності (уміла, гнучка, швидка, непосидюча). Важливою характеристикою у цьому описі є також здатність виражати свої емоції та психологічні стани “мовою тіла" (жести, міміка, драматизація).

При виявленні розвиненого кінестетичного виду інтелекту в учнів, можна говорити про розвинені уміння у галузі надання послуг (транспортування, перевезення вантажів, доставлення замовлень, монтаж різних конструкцій, прибирання, обслуговування); спорті (легкоатлетичні види спорту); акторському мистецтві (виконання акторських, пантомімічних ролей, танці, хореографічні постановки); народноприкладному мистецтві (різні види народних ремесел); модельному (презентація колекцій одягу) та туристичному бізнесі (організація подорожей, екскурсій на свіжому повітрі, рекреаційних та відновлюваних заходів, “зелений туризм") та ін.

Учні, що мають найбільш розвинений саме цей вид інтелекту, можуть себе реалізувати у таких професіях: професійний спортсмен, учитель фізкультури, реабілітолог, фізіотерапевт, хірург, механік, майстер народного мистецтва, столяр, ювелір, фермер, лісник та ін. [11].

6. Міжособистісний інтелект визначається як здатність розуміти інших людей, їх настрої, почуття та мотиви їх поведінки. Учителі початкових класів, проводячи діагностичні спостереження за розвитком міжособистісного виду інтелекту в учнів, мають відзначати, наскільки вони активно вступають у взаємовідносини з іншими, чи їм подобається бути частиною команди і як вони при цьому вибудовують стосунки (знаходять компроміси у складних ситуаціях, коли інші займають радикальну позицію, виступають посередниками у врегульованих конфліктів, із розумінням ставляться до думки інших), чи багато у них друзів. Слід зазначити, що цей вид інтелекту розвивається завдяки діяльності, спрямованій на подолання проблем і конфліктів між людьми або в процесі співпраці, коли необхідна взаємодія з іншими.

Виявивши в учнів добре розвинений цей вид інтелекту, можна констатувати наявність у них таких умінь: спілкуватися, виявляти співпереживання, навчати й навчатися, оцінювання інших, консультування та наставництва, переконувати, мотивувати, надихати, заохочувати, просувати, наглядати, продавати, координувати взаємодію (співпраця, налагодження переговорів, проведення співбесід, посередництво, делегування повноважень, коучінг, протистояння, залагодження конфліктів, набір персоналу)

Учням з яскраво вираженим міжособистісним інтелектом можна в майбутньому рекомендувати вибір таких професій: менеджер, директор школи (або будь-якого іншого закладу чи установи), співробітник з підбору кадрів, арбітр, соціолог, політик, антрополог, лікар, вчитель, секретар, медсестра, продавець, туристичний агент та інші - усі професії, що пов'язані зі взаємодією й контактами з людьми [11].

Батькам дітей з розвиненим міжособистісним видом інтелекту учителям початкових класів доречно порекомендувати спрямовувати коло професійних зацікавлень у напрямку професій, що передбачають викладання, співпрацю та вплив на інших, пом'якшення й усунення конфліктів, допомогу і опіку.

Учні, у яких розвинений внутрішньоособистісний вид інтелекту, в міжособистісній взаємодії добре вміють контролювати свої емоції та поведінку, діяти відповідно до власних сил, своєі продуктивності. Учителі початкових класів відзначають, що таким учням притаманна схильність до пошуку та переживання внутрішніх емоцій, осмислення різних справ, процесів та явищ, їм подобається працювати самостійно, вони, часом, сором'язливі, мають добре розвинені творче мислення, інтуїцію, силу волі та внутрішню мотивацію (для отримання чогось їм не потрібна зовнішня мотивація до дій). Такі учні завжди мають власну думку з більшості питань й до них охоче звертаються за порадою інші. Розвиток цього виду інтелекту в учнів відбувається шляхом надання їм можливості самовираження. 


\section{ПІДГОТОВКА ВЧИТЕЛІВ ПОЧАТКОВИХ КЛАСІВ ДО РОЗВИТКУ ПРОФЕСІЙНИХ ЗАЦІКАВЛЕНЬ УЧНІВ НА ОСНОВІ ВИКОРИСТАННЯ ТЕОРІЇ МНОЖИННИХ ІНТЕЛЕКТІВ}

Для діагностики в учнів внутрішньоособистісного виду інтелекту, вчителям початкових класів бажано залучити до співпраці батьків, провести 3 ними роз'яснювальні бесіди щодо критеріїв діагностики, запропонувати анкетування, у якому вони мають відповісти на такі запитання: Чи вважаєте Ви, що Ваша дитина обмірковує (усвідомлює) свої думки, почуття та емоції, аналізує їх? Чи вважаєте Ви, що Ваша дитина шукає пояснення різних настроїв, поглядів, поведінки, способів реагування в тій чи іншій ситуації? Чи вважаєте Ви, що Ваша дитина розмірковує, цікавиться й шукає відповіді на філософські питання (наприклад, про сенс життя і смерті, людську природу, суть добра і зла та ін.)? Чи вважаєте Ви, що Ваша дитина вміє визначати сильні й слабкі сторони своєї особистості, визначити свої переваги й недоліки, має високу внутрішню мотивацію? Чи вважаєте Ви, що Ваша дитина виявляє спроби, намагається жити за власними правилами та переконаннями? Ваша дитина залюбки витрачає час на роздуми про себе та власне життя (вважає, що найголовніше - це ваше внутрішнє вдосконалення)? Ваша дитина записує різні думки, роздуми про події, що відбулись чи мають відбутися, висновки зі зроблених спостереження за собою та іншими людьми? Ваша дитина любить працювати самостійно? Ваша дитина Вимагає необхідності пояснень чому й для чого необхідно виконувати те чи інше конкретне завдання?

Результати такої діагностики дають можливість виявити рівень розвитку внутрішньоособистісного виду інтелекту. Розвиненість в учнів цього виду інтелекту дає можливість розглядати в майбутньому такі професії: педагог, вихователь, психолог, теолог, терапевт, консультант, соціальний працівник, науковець, викладач психології, священнослужитель, художник, фахівець 3 планування, підприємець та ін. Це професії, що потребують умінь заглиблюватись у себе, розуміти інших, сутність природи. Обирають такі професії ті, хто має багатство внутрішнього світу, живе у сфері духу, а не тіла. Опосередковано це потрібно в різних професіях, пов'язаних із роботою 3 людьми й для людей. Цей вид інтелекту людей, які люблять усамітнення, монахів, учених, що здебільшого не пристосовані до прози життя й навколишньої дійсності, моральних авторитетів, священиків, філософів, законослухняних людей, що беззаперечно виконують закони, правила, кодекси, приписи.

Повертаючись до того, що кожна людина має всі види інтелекту, але розвинені різною мірою й поєднанні, учителю початкових класів важливо знайти домінантні й найбільш активовані конфігурації типів інтелекту в учнів для того, щоб не тільки їх розвивати 3 метою формування професійних зацікавлень, а й спробувати активізувати недомінантні типи інтелекту, розширюючи тим самим коло можливостей подальшої самореалізації особистості учнів. Так, зокрема, Г. Гарднер виявив, що поєднання мовного (лінгвістичного) та особистісного (внутрішньо-особистісного і міжособистісного) видів інтелекту є важливими у професіях, пов'язаних із соціальною сферою, підприємництвом, орієнтованим на людей; математично-логічний вид інтелекту - у професіях, пов'язаних зі збором та обробкою даних, більш статичною роботою за столом; рухово-кінестетичний, природничий та просторовий види інтелекту потрібні в професіях предметної сфери; мовний, логічноматематичний, музичний та просторовий види інтелекту будуть необхідні в мистецьких та дослідницьких професіях, що потребують розвинутого креативного мислення, продукування різних ідей [10].

Наголосимо на тому, що людина має добре розвинутий не один, а декілька видів інтелекту. Ці індивідуальні особливості, що увиразнюються в поєднанні декількох видів інтелекту, є відбиттям наших особистих нахилів та інтересів, того професійного шляху, який ми обираємо за покликом серця. Визначаючи та розвиваючи групу різних видів інтелекту (здібностей, особистих уподобань, можливостей, інтересів, а можливо й талантів), яких є найбільше, які в нас домінують, можна вибрати не тільки омріяний (природовідповідний) професійний шлях, а й вибудувати власну траєкторію особистісного розвитку загалом.

Теорія множинного інтелекту отримала велику популярність у світовій науковій спільноті. Так, зокрема, Томас Армстронг у книзі "Сім видів інтелекту: виявити їх у собі та розвинути”, розвиваючи ідеї Г. Гарднера, зазначає: "У кожної людини проявлені всі види інтелектів, але нерівномірно, тобто вони функціонують у кожному випадку індивідуально, унікально. Людина може мати розвинуті всі види інтелектів, або лише кілька; у більшості людей наявними $є$ різні здібності, але деякі 3 них можуть бути не виявленими; людина виявляє власні здібності поступово; всі види інтелектів інтегруються один 3 одним, жоден з них не реалізується автономно (самостійно); людина може бути розумною з усіх боків, у неї можуть бути представлені різні комбінації розвинутих видів інтелектів, і тому немає жодного стандарту, який би чітко визначав 


\section{ПШДГООВКА ВЧИТЕЛІВ ПОЧАТКОВИХ КЛАСІВ ДО РОЗВИТКУ ПРОФЕСІЙНИХ ЗАЦІКАВЛЕНЬ УЧНІВ НА ОСНОВІ ВИКОРИСТАННЯ ТЕОРІЇ МНОЖИННИХ ІНТЕЛЕКТІВ}

(атрибути, характеристики, критерії) інтелект даної людини" [9].

За теорією множинного інтелекту Г. Гарднера, кожна людина індивідуальна й по-різному розвиває свій потенціал, свої види інтелектів. Плануючи власний розвиток, кожен повинен враховувати власні здібності та вроджені схильності (задатки) - відповідно до них вибирати освіту, обирати відповідну нам професію та спосіб життя, які становлять основу нашого задоволення життям [4]. Тому саморозвиток повинен бути усвідомленим та індивідуальним вибором, а не випадковістю чи способом розвитку, нав'язаним іншими.

Аналізуючи вибір професії у контексті концепції теорії множинного інтелекту, слід зауважити, що учителям, які діагностують та спрямовують учнів на той чи інший професійний шлях, важливо постійно використовувати моніторинг актуальних професій або прогностику професій, які будуть потрібними в найближчому майбутньому, тобто постійно спостерігати за змінами на ринку праці (консультуватися 3 фахівцями в цій галузі). Це відбувається тому, що бажані індивідуальні професійні профілі на ринку праці постійно змінюються. Так, зокрема, офісна робота та робота за комп'ютером потребують добре розвиненого лінгвістичного виду інтелекту, розробка телевізійного та графічного інтерфейсів користувача (програмування, що дозволяє взаємодію між додатками та користувачем) розвиненого просторового інтелекту. Місця роботи, пов'язані з діяльністю в електронноцифровому просторі та Інтернеті, підвищила попит на лінгвістичний, логіко-математичний та просторовий інтелект. Професіі, що стосуються послуг, збільшують попит на осіб з добре розвинутим міжособистісним видом інтелекту.

Висновки та перспективи подальших розвідок. Таким чином, підготовка вчителів початкових класів до формування ранніх професійних зацікавлень учнів з врахуванням основних положень теорії множинного інтелекту $\epsilon$ доцільною, оскільки надає вчителям можливість здійснювати діагностику рівнів розвитку видів інтелекту, відповідно до яких рекомендувати учням можливий перелік професійного спрямування у майбутньому. Проводити кваліфіковане консультування батьків 3 профорієнтації (розвитку професійних інтересів), надавати поради, що стосуються не тільки майбутнього професійного вибору дитини, а й багатьох інших життєвих питань, що потребують розв'язання.

У підготовку вчителів початкових класів до професійної діяльності вважаємо за необхідне ввести навчальні дисципліни, доповнити зміст курсів темами, вивчення яких допомогло б сформувати у них компетентність щодо формування ранніх професійних зацікавлень на основі теорії множинного інтелекту. 'Цей процес почнеться тоді, коли ми визнаємо за необхідне познайомитися зі своїми дітьми, своїми учнями, вихованцями, коли припинимо, з позиції тільки власного, і не завжди вдалого досвіду, нав'язувати їм свої стереотипи мислення, поведінки, допускаючи при цьому безліч помилок у вихованні та спілкуванні з ними, ускладнюючи тим самим своє і їх життя, спільне співіснування, коли ми самі почнемо вчитися жити в гармонії 3 собою й навколишнім нас світом" [7, 209]. Вважаємо, що тільки поважаючи й розуміючи особливості дитини, можна допомогти їй вирости щасливою людиною, здатною любити й поважати себе, інших людей, Всесвіт.

\section{ЛІТЕРАТУРА}

1. Гарднер Говард. Структура разума: теория множественного интеллекта Frames of Mind. The Theory of Multiple Intelligence. Москва, 2007. $512 \mathrm{c}$.

2. Педагогічні науки : теорія, історія, інноваційні технології. 2016. № 4 . С. 11-20.

3. Лещенко М., Гринько В. Використання цифрових технологій у ході реалізації теорії множинного інтелекту в зарубіжних освітніх практиках. Фізико-математична освіта / гол. ред. О. В. Семеніхіна та ін. 2019. Вип. 4 (22). C. $79-85$.

4. Лещенко М., Гринько В. Зарубіжний досвід використання теорії множинного інтелекту Говарда Гарднера в навчальному процесі. Педагогічні науки: теорія, історія, інноваційні технологіï. 2017. № 10. С. 113-131. URL: http:// nbuv.gov.ua/UJRN/pednauk_2017_10_13 (дата звернення 01.06.2020).

5. Педагогічна мудрість віків: навч.посіб. / уклад.: В. Л. Омельяненко, А. І. Кузьмінський. Київ, 2009.411 с.

6. Тименко В. Обдарованість дошкільників за теорією Говарда Гарднера. Освіта та розвиток обдарованої особистості. 2014. № 8 (27). C. 84-89.

7. Тимчук Л. І. Методична підготовка вчителів початкових класів до формування професійних інтересів учнів: дис. ... канд. пед. наук : 13.00.04 Академія педагогічних наук України ; Інститут педагоічної освіти і освіти дорослих. Київ, 2010. 298 c.

8. Тимчук Л.І. Прогностично-профорієнтаційна 
робота вчителя початкових класів. Методичний посібник. Київ, 2009.125 с.

9. Armstrong, Thomas (2009). Siedem rodzajów inteligencji - odkryj je w sobie i rozwijaj, tłum. M. Witkowska, Akademia Rozwoju Osobistego, MT Biznes, Warszawa, 2009.

10. Gardner, Howard Five Minds for the Future. Boston, MA: Harvard Business School, 2009. 169p.

11. Wysocka, Ewa Kim jestem i kim mogę się stać- niektóre problemy okresu dorastania związane z wyborem zawodu: Poradnik z serii "Wybór Zawodu" Ministerstwo Edukacji Narodowej, Kraków, 2011. 128 s.

\section{REFERENCES}

1. Gardner Howard (2007). Struktura razuma: teoryia mnozhestvennoho intellekta [The structure of the mind: the theory of multiple intelligence]. Frames of Mind. The Theory of Multiple Intelligence. Moscov, 512 p. [in Ukrainian].

2. Pedahohichni nauky: teoriya, istoriya, innovatsiyni tekhnolohiyi (2016). [Pedagogical sciences: theory, history, innovative technologies]. No. 4, pp. 11-20. [in Ukrainian].

3. Leshchenko, M. \& Grinko, V. (2019). Vykorystannia tsyfrovykh tekhnolohii u khodi realizatsii teorii mnozhynnoho intelektu v zarubizhnykh osvitnikh praktykakh [The use of digital technologies in the implementation of the theory of multiple intelligences in foreign educational practices]. Physical and mathematical education. (Ed.). O.V.Semenikhin and others. Vol.4 (22), pp. 79-85. [in Ukrainian].

4. Leshchenko, M. \& Grinko, V. (2017). Zarubizhnyy dosvid vykorystannya teoriyi mnozhynnoho intelektu Hovarda Hardnera v navchalnomu protsesi [Foreign experience of using the theory of multiple intelligence by Howard Gardner in the educational process]. Pedagogical sciences: theory, history, innovative technologies. No. 10, pp. 113-131. Available at: http://nbuv.gov.ua/UJRN/ pednauk 2017_10_13 (Accessed 01 June 2020). [in Ukrainian].

5. Pedahohichna mudrist vikiv (2009). [Pedagogical wisdom of the ages]. (Ed).V.L. Omelyanenko, A.I. Kuzminsky. Kyiv, 411 p. [in Ukrainian].

6. Tymenko, V. (2014). Obdarovanist doshkilnykiv za teoriyeyu Hovarda Hardnera [Gifted preschoolers according to the theory of Howard Gardner]. Education and development of a gifted personality. No. 8 (27). pp. 84-89. [in Ukrainian].

7. Timchuk, L.I. (2010). Metodychna pidhotovka vchyteliv pochatkovykh klasiv do formuvannya profesiynykh interesiv uchniv [Methodical preparation of primary school teachers for the formation of professional interests of students]. Candidate's thesis. Academy of Pedagogical Sciences of Ukraine; Institute of Pedagogical Education and Adult Education. Kyiv, 298 p. [in Ukrainian].

8. Timchuk,L. (2009). Prohnostychno-proforiyentatsiyna robota vchytelya pochatkovykh klasiv [Prognostic and career guidance work of primary school teachers]. Methodical manual. Kyiv, 125 p. [in Ukrainian].

9. Armstrong, Thomas (2009). Siedem rodzajyw inteligencji-odkryj je w sobie i rozwijaj, tium [Seven births of intelligence - discover it in your room and develop it]. M. Witkowska, Akademia Rozwoju Osobistego, M.T. Biznes, Warszawa. 264 p. [in Polish].

10. Gardner, Howard (2009). Five Minds for the Future. Boston, M.A: Harvard Business School, 169 p. [in English].

11. Wysocka, E. (2011). Kim jestem i kim mogę się stać - niektóre problemy okresu dorastania związane $\mathrm{z}$ wyborem zawodu [Who I am and who I can become - some of the problems of the district of growth related to the choice of plant]. Adviser from the series "Choice of Plant" Ministerstwo Edukacji Narodowej, Kraków, 128 p. [in Polish].

Стаття надійшла до редакції 09.06.2020

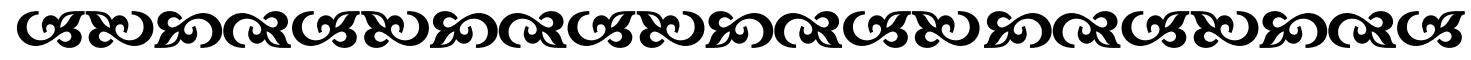

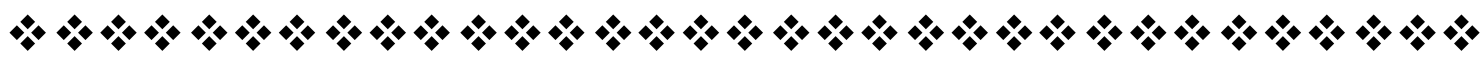

“Корисним для себе ( $і$ для суспільства) буде тільқи той, хто пізнав свою природу. ТТоді людина розуміє свою місію. Своє поқлиқання на землі й виробляє для себе спосіб життя, в основі яқого лежить “споріднена праия". ТТільки так людина може самоствердитися і самореалізуватися, а значить стати щасливою”.

Тригорій Сқоворода украӥнський просвітитель-гуманіст, ббілособ, поет, педагог

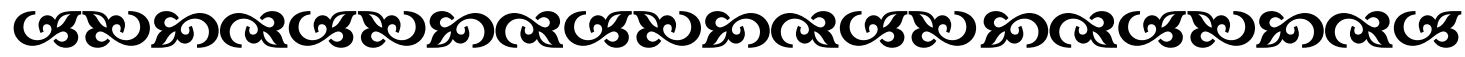

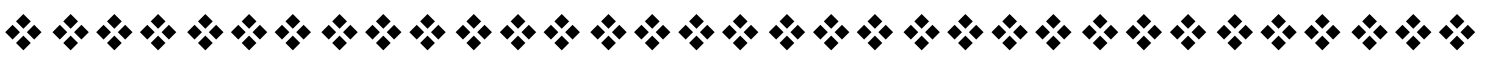

